\title{
The Reversible Competitive Inhibition of Bovine Milk Acid Phosphatase by Orange II and Congo Red
}

\author{
Yasuo Kuzuya and Tamotsu Tanahashi \\ Department of Poultry and Animal Sciences, Faculty of Agriculture \\ Gifu University, Kakamigahara 504 \\ (Received October 6, 1977)
}

\begin{abstract}
Through the addition of a further stage using CM-Sephadex C-50 chromatography, the bovine milk acid phosphatase was purified to yield an enzyme with a specific activity of about 2.7 unit/mg protein which made it possible to conduct a detailed study in the use of orange II and congo red as reversible competitive inhibitors for bovine milk acid phosphatase. Kinetic studies with purified bovine milk acid phosphatase showed that both orange II and congo red acted as competitive inhibitor with Ki values of $8.7 \times 10^{-5} \mathrm{M}$ and $7.0 \times 10^{-6} \mathrm{M}$, respectively. The sample analyzed after $5 \mathrm{~min}$ of incuba* tion showed $72 \%$ inhibition of enzyme activity by orange II and $90 \%$ by congo red. When enzyme inhibited by either orange II or congo red was applied on a Sephadex G-25 column, inhibition was nearly restored. The rate of recovery of enzyme activity was $75 \%$ for orange II and 84\% for congo red. The results obtained in this experiment showed that both orange II and congo red were reversible competitive inhibitors for bovine milk acid phosphatase.
\end{abstract}

It has been generally known for a number of years that bovine milk contains active acid phosphatase (orthophosphoric monoester phosphohydrolase, E.C. 3.1.3.2).

Much studies have been done concerning the Kinetics of bovine milk acid phosphatase ${ }^{1-4}$. Also, numerous studies have shown that milk acid phosphatase is inhibited by a number of agents ${ }^{1,3,5-7)}$, e.g., divalent cations and certain anions. However, relatively high concentrations of these anionic and cationic inhibitors are required to achieve significant inhibition of the enzyme.

The reversible competitive inhibition of bovine milk acid phosphatase has not been widely investigated. But, KuzuYa et al.4) reported bovine milk acid phosphatase to be inhibited competitively by dye, trypan blue with $\mathrm{Ki}$ of $9.8 \mu \mathrm{M}$. They confirmed that this inhibition was reversible and was in rapid equlibrium with the enzyme.

The present paper extends the inhibition investigations of bovine milk acid phosphatase by dyes of orange II and congo red, and attempts to find out if these dyes can serve as reversible competitive inhibitor for acid phosphatase.

\section{Materials and Methods}

Bovine milk was obtained from Holstein-Friesian cow which kept on the University farm.

Purification of acid phosphatase: Ten liters of raw skim milk was used to prepare the acid phosphatase. The method of preparation described previously8), consisting of extraction with ionexchange resin (Amberlite CG-50 Type II, $\mathrm{NH}_{4}{ }^{+}$form) followed by gel filtration (Sephadex $\mathrm{G}^{-}$ 100) was extended by the addition of a further stage using CM-Sephadex C-50, that is, after Jap. J. Zootech. Sci., 49, (5): 358-363. 358 1978. 5. 


\section{Reversible Competitive Inhibition of Acid Phosphatase}

Sephadex G-100 gel filtration, the pooled enzyme-containing fractions were applied to a column $(18 \mathrm{~cm} \times 2.5 \mathrm{~cm})$ of CM-Sephadex C-50 previously equilibrated with $0.3 \mathrm{M}$ sodium acetate buffer (pH 4.8), the enzyme sample was washed on to the column with a further $50 \mathrm{~m} l$ of this buffer and the column then eluted with a linear ionic-strength gradient from 0.4 to $0.9 \mathrm{M}$. The first reservoir contained $0.4 \mathrm{M}$ sodium acetate buffer $\mathrm{pH} 4.8(350 \mathrm{ml})$ and the second reservoir $0.9 \mathrm{M}$ sodium acetate buffer $\mathrm{pH} 4.8(350 \mathrm{~m} l)$. Fractions of $5 \mathrm{~m} l$ were collected and analyzed for protein through the measurment of absorbance at $280 \mathrm{~nm}$. Portions $(0.1 \mathrm{ml})$ of each fraction were taken for assay of acid phosphatase activity ${ }^{8}$. Fractions containing enzyme were pooled and concentrated to approximately $10 \mathrm{~m} l$ by dialysis against Sephadex G-25.

Polyacrylamide disc gel electrophoresis was carried out by the same method as reported previously8).

Kinetic studies: Measurements of bovine milk acid phosphatase activity were obtained at 7 different $p$-nitrophenyl phosphate substrate concentrations in the 0.20 to $5.0 \mathrm{mM}$ range in $0.1 \mathrm{M}$ sodium acetate buffer ( $\mathrm{pH}$ 4.8). Then, LineweAVER-Burk plots were drawn. Values for the Ki (constant of inhibition) by orange II and congo red were determined as described previously8).

Specific activities were performed as described previously ${ }^{88}$.

\section{Results and Discussion}

Purification of acid phosphatase: The application of an additional stage during purification which involved the use of CM-Sephadex $\mathrm{C}-50$ in chromatography on ion-exchange caused an increase in the specific activity from the value of $0.22 \mathrm{unit} / \mathrm{mg}$ protein as used in previous studies $^{9)}$ to about 2.7 unit/mg protein. Typical results of this purification stage are shown in Fig. 1. Also, the enzyme-containing fractions were pooled as indicated by the bar. As the

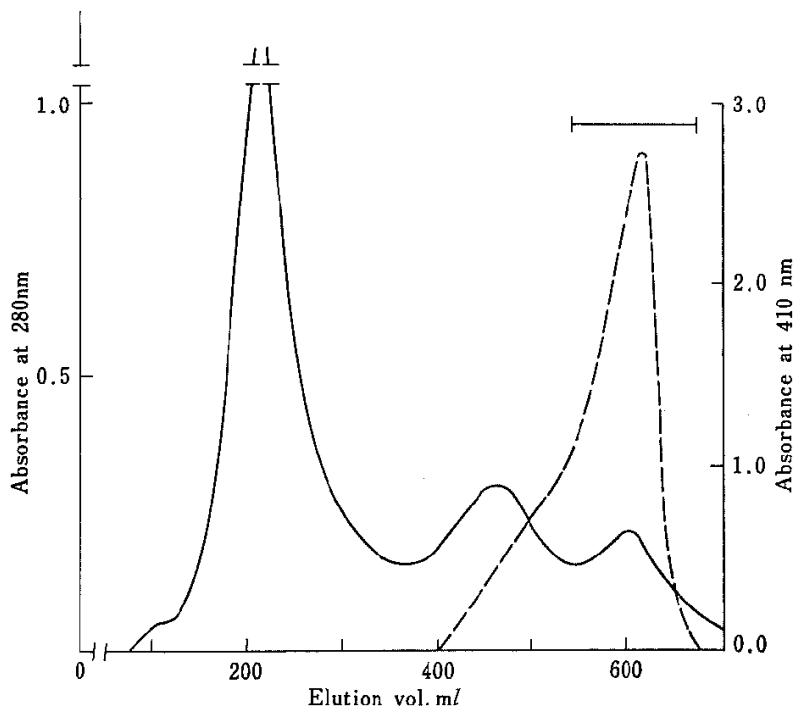

Fig. 1. The further fractionation of bovine milk acid phosphatase material on a column $(18 \mathrm{~cm} \times 2.5 \mathrm{~cm})$ of $\mathrm{CM}-$ Sephadex $\mathrm{C}-50$ using a $0.4-0.9 \mathrm{M}$ sodium acetate buffer gradient at $\mathrm{pH} 4.8$. — , protein absorbance at $280 \mathrm{~nm} ; \cdots \cdots$, enzyme activity. Enzyme-containing fractions were pooled as indicated by the bar. 


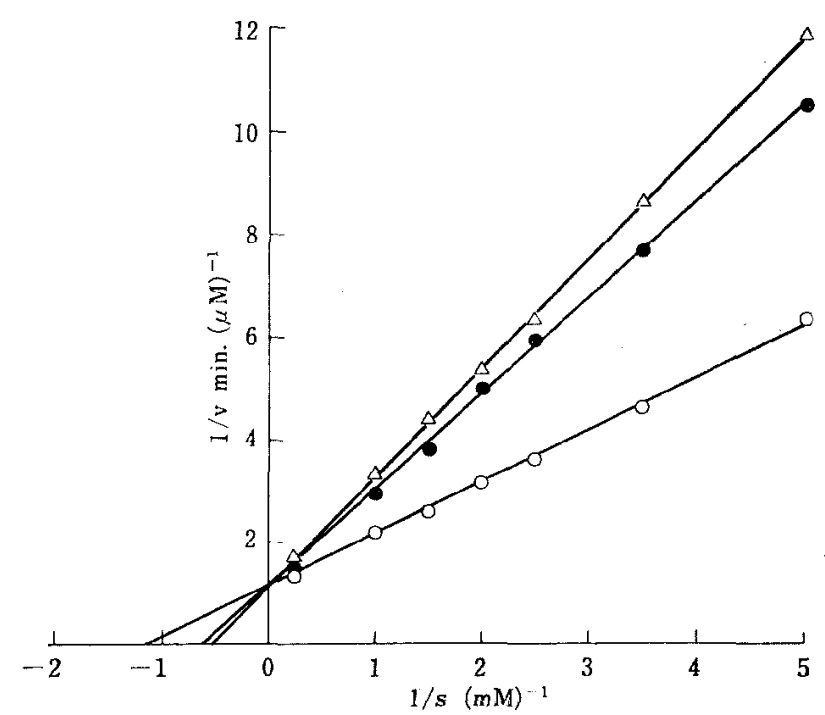

Fig. 2. LiNEWEAver-Burk plots for the hydrolysis of p-nitrophenyl phosphate by bovine milk acid phosphatase in $0.1 \mathrm{M}$ sodium acetate buffer of pH 4.8. Enzyme preparation and substrate alone (O) in the presence of $7.6 \times 10^{-5} \mathrm{M}$ orange II $(\bullet)$ and in the presence of $8 \times 10^{-6} \mathrm{M}$ congo red $(\Delta)$.

result of purification with the gel filtration of CM-Sephadex C-50, acid phosphatase was purified to $10^{5}$-fold from skim milk $\left(2.7 \times 10^{-5}\right.$ unit/mg protein). The enzyme obtained showed a single protein band on polyacryl-amide disc gel electrophoresis at $\mathrm{pH}$ 8.3.

Inhibition by orange II and congo red: Kinetic studies were conducted to determine the inhibition of bovine milk acid phosphatase by orange II and congo red. LINEWEAVER-BURK (Fig. 2) obtained at $\mathrm{pH} 4.8$ gave a $\mathrm{Km}$ value of $0.86 \mathrm{mM}$ with $p$-nitrophenyl phosphate as substrate. Orange II and congo red were both competitive inhibitors (Fig. 2) of the hydrolysis of $p$ nitrophenyl phosphate at $\mathrm{pH} 4.8$ with $\mathrm{Ki}$ values of $8.7 \times 10^{-5} \mathrm{M}$ and $7.0 \times 10^{-6} \mathrm{M}$, respectively. The calculated values were considerably lower than the Ki values ${ }^{1,3)}$ for bovine milk acid phosphatase with divalent cations or anions and the $\mathrm{Ki}$ value for congo red was in general agreement with that of trypan blue as inhibitor of the hydrolysis of $p$-nitrophenyl phosphate reported by KuzUya et al. ${ }^{4}$.

In order to determine the effect of the incubation time on the inhibition of acid phosphatase by orange II and congo red, both reagents were tested. Both orange II $\left(2.5 \times 10^{-4} \mathrm{M}\right)$ and congo red $\left(2.5 \times 10^{-5} \mathrm{M}\right)$ demonstrated that maximal inhibition had occurred within $5 \mathrm{~min}$, the time of first sampling as shown in Fig. 3 and Fig. 4, after the inhibitor was added to the enzyme $(0.25 \mathrm{unit} / \mathrm{ml})$. The first sample analyzed after $5 \mathrm{~min}$ of incubation showed $72 \%$ inhibition of enzyme activity by orange II and $90 \%$ by congo red. Upon prolonged incubation of up to $14 \mathrm{hr}$, orange II inhibited the activity of the original enzyme by $82 \%$ and congo red by $95 \%$. Thus, it appeared that the binding ability of these two inhibitors to the enzyme was fairly rapid and readily attainable.

In order to prove the reversibility of the enzyme-inhibitor complex, acid phosphatase-orange II complex was prepared from incubation of $2.0 \mathrm{~m} l$ of acid phosphatase $(0.25 \mathrm{unit} / \mathrm{m} l)$ and 2.0 $\mathrm{ml}$ of orange II $\left(2.5 \times 10^{-4} \mathrm{M}\right)$ for $14 \mathrm{hr}$ at $37^{\circ} \mathrm{C}$. For the preparation of acid phosphatase-congo 


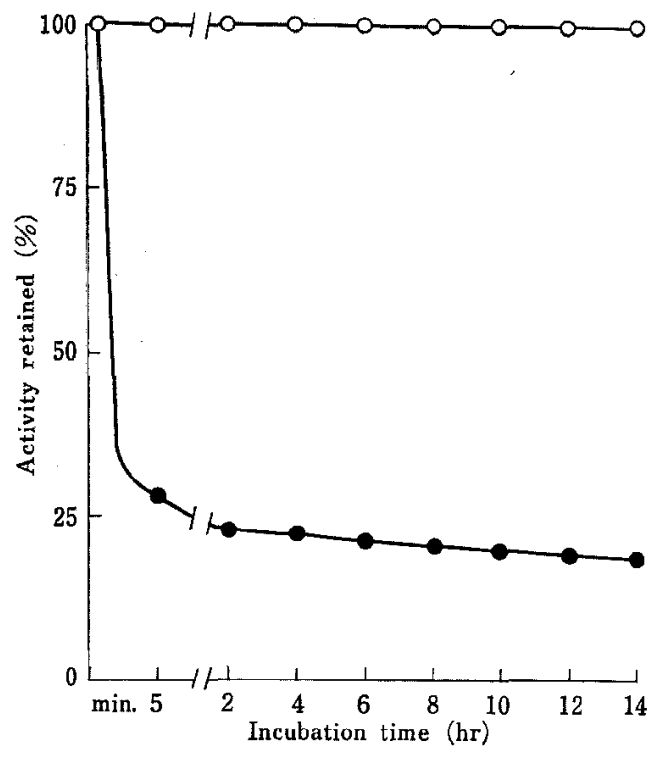

Fig. 3. Inhibition of bovine milk acid phosphatase by orange II. The enzyme solution $(0.25$ unit $/ \mathrm{m} l)$ adjusted to $\mathrm{pH} 4.8$ was mixed with an equal volume of $2.5 \times$ $10^{-4} \mathrm{M}$ orange II adjusted to $\mathrm{pH} 4.8$ by the addition of sodium acetate buffer. The mixture was incubated at $37^{\circ} \mathrm{C}$ in the dark and $0.1 \mathrm{~m} l$ aliquots were withdrawn after various time intervals for assay of acid phosphatase. $\mathrm{O}-\mathrm{O}$, no orange II; $\bullet-\bullet$, the presence of orange II.

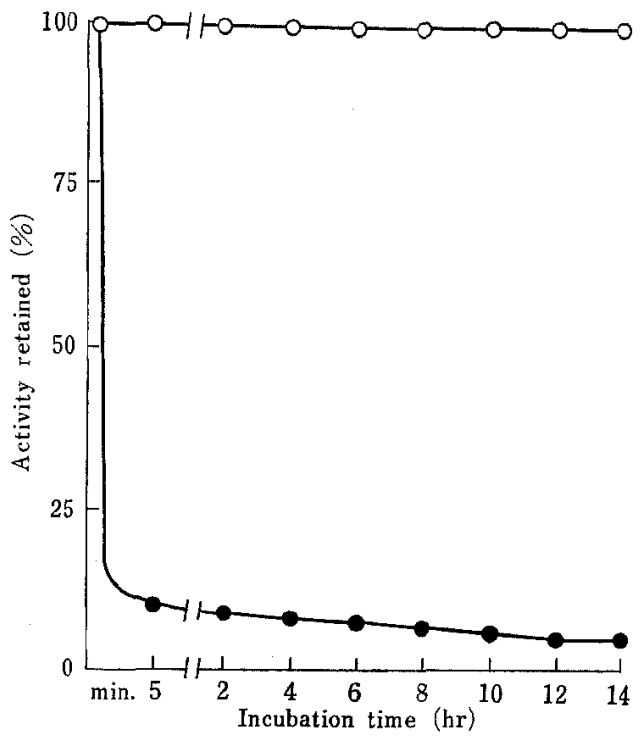

Fig. 4. Inhibition of bovine milk acid phosphatase by congo red. The enzyme solution $(0.25$ unit $/ \mathrm{m} l)$ adjusted to $\mathrm{pH} 4.8$ was mixed with an equal volume of $2.5 \times$ $10^{-5} \mathrm{M}$ congo red adjusted to $\mathrm{pH} 4.8$ by the addition of sodium acetate buffer. The mixture was incubated at $37^{\circ} \mathrm{C}$ in the dark and $0.1 \mathrm{~m} l$ aliquots were withdrawn after various time intervals for assay of acid phosphatase. $\mathrm{O}-\mathrm{O}$, no congo red; the presence of congo red.

red complex in which congo red was used as the inhibitor, a concentration of $2.5 \times 10^{-5} \mathrm{M}$ was used. When both acid phosphatase-orange II complex and acid phosphatase-congo red complex were subjected to dialysis (Visking tubing, size: $36 / 32$ ) against $\mathrm{H}_{2} \mathrm{O}$ or $0.1 \mathrm{M}$ sodium acetate buffer ( $\mathrm{pH} \mathrm{4.8)}$ for the period of up to $24 \mathrm{hr}$, almost no decrease in their concentration was observed. Also, neither of the attempts to remove orange II or congo red from the respective enzyme-inhibitor complex by ultra-filtration using Amicon cell with a PM-10 membrane was successful. However, the enzyme inhibited by either orange II or congo red was nearly restored with Sephadex G-25. When the acid phosphatase-orange II complex was applied on a Sephadex G-25 colume, about 75\% of the enzyme activity was recovered. As is observable in Fig. 5, discrete enzyme and protein peaks were obtained by Sephadex $\mathrm{G}-25$ column treatment. Further, Sephadex G-25 column could be used repeatedly. When the acid phosphatase-congo red complex was applied on a Sephadex G-25 column, about $84 \%$ of the enzyme activity was recovered (Fig. 6), and Sephadex G-25 formed an irreversible reaction with congo red. Thus, the Sephadex G-25 used in these experiments could be an inhibitor readily removed from the enzyme-inhibitor complex.

The reaction which facilitate the development of affinity chromatography as an effective tool for the enzyme purification is: a) the specificity of the reaction and b) the reversibility of the reaction. Consequently, it is important to establish the reversible competitive inhibitor for the 


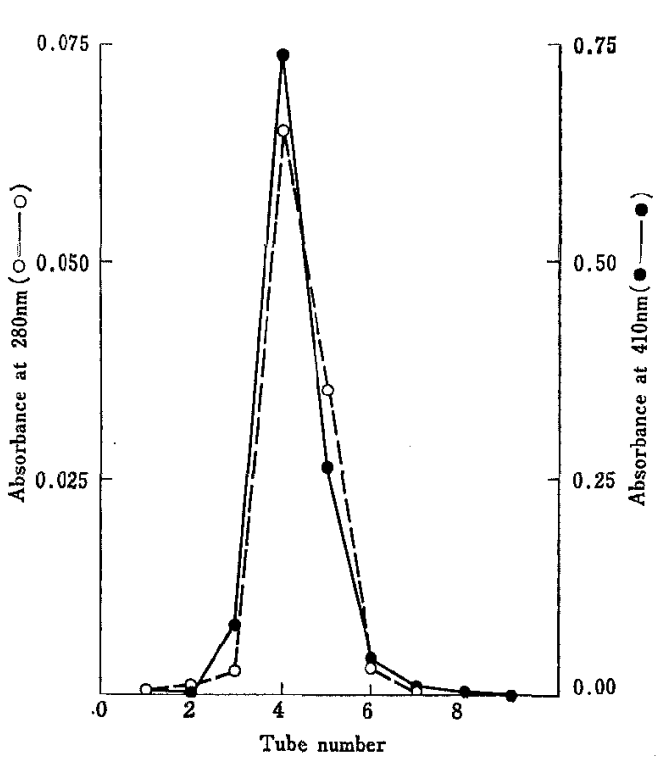

Fig. 5. Chromatogram of acid phosphatase-orange II complex on Sephadex G-25. Column size $1.5 \mathrm{~cm} \times 2.3 \mathrm{~cm}$; flow rate $40 \mathrm{~m} l /$ $\mathrm{hr}$ and $4 \mathrm{~m} l /$ tube; $0-0$, protein absorbance at $280 \mathrm{~nm} ; \bullet-\bullet$, enzyme actívity. Acid phosphatase-orange II complex was prepared f $10 \mathrm{~m}$ incubation of $0.5 \mathrm{ml}$ of acid phosphatase $(0.25 \mathrm{unit} / \mathrm{m} l)$ and $0.5 \mathrm{~m} l$ of $2.5 \times 10^{-4} \mathrm{M}$ orange II for $14 \mathrm{hr}$ at $37^{\circ} \mathrm{C}$ before chromatography.

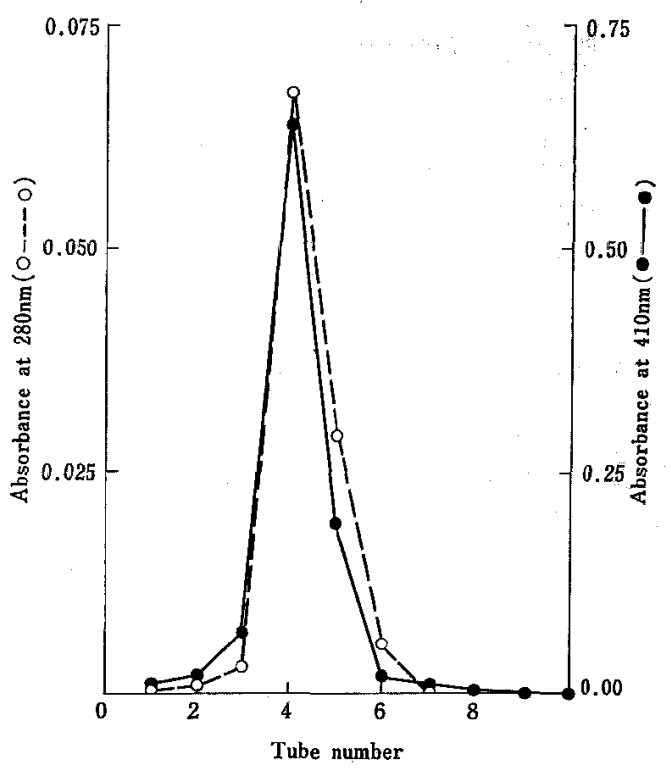

Fig. 6. Chromatogram of acid phosphatase-congo red complex on Sephadex G-25. Column size $1.5 \mathrm{~cm} \times 23 \mathrm{~cm}$; flow rate $40 \mathrm{ml} /$ $\mathrm{hr}$ and $4 \mathrm{~m} l /$ tube; $\bigcirc-0$, protein absorbance at $280 \mathrm{~nm} ; \bullet-\bullet$, enzyme activity. Acid phosphatase-congo red complex was prepared from incubation of $0.5 \mathrm{~m} l$ of acid phosphatase $(0.25 \mathrm{unit} / \mathrm{m} l)$ and $0.5 \mathrm{~m} l$ of $2.5 \times 10^{-5} \mathrm{M}$ congo red for $14 \mathrm{hr}$ at $37^{\circ} \mathrm{C}$ before chromatography.

isolation of acid phosphatase. The results obtained suggested that both orange II and congo red could be effective affinity ligands for the preparation of bovine milk acid phosphatase as a reversible competitive inhibitor.

\section{References}

1) Andrews, A.T. and C. Pallavicini, Biochim. Biophys. Acta, 321: 197-209. 1973.

2) Andrews, A.T., J. Dairy Res., 41: 229-237. 1974.

3) Kuzuya, Y., Res. Bull. Fac. Agr. Gifu Univ., No. 39: 269-272. 1976.

4) KuzuYa, Y., W.F. Wagner, A. Kilara and K.M. Shahani, Milchwiss., 31: 358-362. 1976.

5) Muller, J.E. C., J. Dairy Res., 25: 288-295. 1950.

6) Bingham, E. W., L. Taaewicz and C. A. Zittre, J. Dairy Sci., 44: 1247-1257, 1961.

7) Bingham, E.W, and C.A. Zittle, Arch. Biochem. Biophys., 101: 471-479. 1963.

8) Kuzuya, Y. and T. Tanahashi, Jap. J. Zootech. Sci., 48 (7): 354-360. 1977.

9) Kuzuya, Y., Res. Bull. Fac. Agr. Gifu Univ., No. 39: 263-268. 1976. 


\title{
オレンジII およびコンゴーレッドによる牛乳酸性
}

ホスファターゼの可逆的楛抗阻害

\author{
葛谷泰雄・棚橋 保
}

岐皁大学農学部, 各務原市 504

\section{牛乳より酸性ホスフォターゼを比活性約 2.7 単位に精} 製し，オレンジIIおよびコンゴーレッドによる本䣼素の 可逆的捛抗阻害について検討した。オンンジIおよびこ ンゴーレッドは本醉素に拮抗阻害削として作用し，反応 5 分後においてオレンジாにより活性の $72 \%$ が，また コンゴーレッドによって 90\% が阻害された。 それらの
阻害定数はそれぞれ $8.7 \times 10^{-5} \mathrm{M}$ および $7.0 \times 10^{-6} \mathrm{M} て ゙$ あっだ、な、オレンジ円およびコンゴーレッドによっ て阻害された醉素はいずれも Sephadex G-25 カラム処 理によって，オレンジ【では 75\%，コンヨ゙ーレッドで は 84\%を回復した.したがって，オレンジ版よびュン ゴーレッドは本醉素に可逆的拮抗阻害剂であった。 